\title{
Solidarity in Times of Crisis
}

\author{
Amina Boutabia \\ Chouaib Doukkali University, Eljadida, Morocco \\ a.boutabia74@gmail.com
}

DOI: http://doi.org/ 10.36892/ijlls.v4i1.788

$\begin{array}{ll}\begin{array}{l}\text { Received: } \\ \text { 19/12/2021 }\end{array} & \begin{array}{c}\text { Abstract } \\ \text { The concept of solidarity is certainly one of the most challenging among the } \\ \text { Accepted: }\end{array} \\ \text { concepts forming the constellation of social and political thought. Not only } \\ \text { because of its use in a variety of discourses, but also because it is one of the } \\ \text { most influential concepts despite the fact that it is still undertheorized. At the } \\ \text { heart of the complexity is the ambiguity between the normative and descriptive } \\ \text { Keywords: } & \text { usages of the concept. It seems that this ambiguity is clearly reflected in this } \\ \text { solidarity, Covid-19 } & \text { time of Covid-19 pandemic which has revealed that both individuals and } \\ \text { pandemic, crisis, } & \text { nations can demonstrate both solidary and anti-solidary actions } \\ \text { macro-level } & \text { simultaneously. This paper is an attempt to understand these contradictory } \\ \text { solidarity, micro- } & \text { conducts in the light of the history and development of the concept. Thus, the } \\ \text { level solidarity } & \text { following questions are addressed: First, at a macro level, why do many } \\ & \text { countries behave towards each other in an anti-solidary manner? Second, why } \\ & \text { do individuals, despite their denomination and learning show a lack of } \\ & \text { solidarity towards the most unfortunate people? Solidarity ethics appears in } \\ \text { religious, philosophical, and humanitarian discourses, so, what makes these } & \text { discourses extremely ineffective in times when solidarity is most needed? }\end{array}$

\section{INTRODUCTION}

The concept of solidarity is indisputably one of the most challenging among the concepts forming the constellation of social and political thought. Not only because of its use in a variety of discourses, but also because it is one of the most influential concepts despite the fact that it is still undertheorized. For example, the World Health Organization (WHO) headquarters in Geneva, Switzerland, has established a 'Solidarity Fund' with contributors from multiple donors to provide support for those who need it most. Also, the WHO and its partners have launched 'Solidarity Trials' to test the efficiency of a number of vaccines (Al-Mandhari et al, 2020, p. 492).

At the heart of the complexity is the ambiguity between the normative and descriptive usages of the concept. This fact-norm ambiguity becomes certainly the clearest in times of crises as the concept appears to be muddy and in need of clarification. Indeed, a great deal has been learned on the subject of solidarity in recent times. Putting aside what is acquired through the process of socialization by means mainly of school and religion, solidarity represents practically all what civil society is about. We are encouraged in the same way as we encourage 


\section{Solidarity in Times of Crisis}

others to invest a little time, money, and effort on solidary activities. However, in this time and age, more specifically, the age of Covid-19 pandemic, ideas and actions seem to be in a continuous state of change and the values that call for solidarity are no exception (Alfiras et al., 2020). Indeed, these values seem to be the ones that are most at stake; they are being discussed, questioned, and even challenged.

In the first weeks of the Corona virus outbreak, there has been noticed a great deal of "confusion" among Moroccan people in particular and people worldwide in general as everybody appeared to be torn out between two types of attitudes reflected by conflicting or contradictory patterns of conducts; the urgent need to fulfill one's personal requirements through panic buying which reflects perhaps the activation of a kind of survival instinct on one hand, and the pressing desire to lend a hand to others revealing probably a feeling of compassion with the most needy or perhaps unfortunate people who had lost their jobs due to the outbreak on the other (on panic buying, see O'Connell et al. (2021) among others). Therefore, it seems only fair to question everything since the whole world seems to have grown greedy and self-centered when the time has come for solidarity to manifest. Unfortunately, this observation was not limited to individuals but was also noticed among nations as they grew hostile to each other as evidenced by official statements made by different leaders. Tomasini (2021) cites a number of examples illustrating solidary actions by both individuals and countries belonging to the European Union as opposed to the aggressive attitude of other nation leaders such as Donald Trump for instance.

It is this observation that was at the origin of the idea of this paper. In other words, this paper is an attempt to understand the reason why people and nations, can adopt, in the same context, two contradictory types of behavior: solidary and anti-solidary. Nonetheless, this shouldn't be astonishing for the simple reason that it is times of crisis that trigger development and revision of concepts and the concept of solidarity is no exception. In other words, the concept of solidarity needs to be revised and revisited in the light of crises as many legitimate questions arise:

i. First, at a macro level, why do many countries behave towards each other in the way they do?

ii. Second, why do people, despite their denomination and learning behave in an antisolidary manner?

iii. What happened to all the teachings, be they religious, philosophical, or humanitarian? This paper is thus organized as follows: the second section attempts to define the key concept under investigation namely solidarity. Section two dwells more on the concept by 
characterizing it in terms of distinctive features and situation types. The following section deals with solidarity and social groups, namely at the level of community, society and humanity. Then the situation of Covid 19 pandemic is discussed in section four. Finally, the paper is concluded.

\section{DEFINING SOLIDARITY}

Before attempting to understand this puzzling situation, let us first look at the way the key concept discussed in this paper has been defined. Solidarity generally refers to a kind of awareness of shared interests, objectives, and sympathies creating a psychological sense of unity of groups or classes. It refers to the ties in society that bind people together as one. What forms the basis of solidarity and how it is implemented varies between societies. In developing societies, it may be mainly based on kinship and shared values while more developed societies accumulate various theories as to what contributes to a sense of solidarity, or rather social cohesion. These fundamentals of solidarity, i.e., kinship and social cohesion bring to mind Durkheim's typology of solidarity, i.e. mechanical solidarity for undifferentiated societies vs. organic solidarity which finds its basics in labor division in "more modern societies".

Etymologically, the word "solidarity" derives from Latin: in the Roman Law obligatio in solidum involved the group liability of joint debtors. This is also the sense of the French word solidarite in the Encyclopedia of 1765, and in Napoleon's Code Civil 1804. Around the 1840s the term was adopted in German and English, and was politicized for example by the international labor movement, and was adopted to social sciences. Of the classics of sociology, especially Émile Durkheim adopted the word as part of his fundamental terminology. Gradually the word came to be used in a broader meaning of emotionally and normatively motivated readiness for mutual support, as in the slogan "one for all and all for one" (Laitinen \& Bessi, 2014, p. 1). The Arabic equivalent taDaamun and takaaful both referring to solidarity entail more or less the same interpretation though it doesn't appear in this particular form in LissanLaarab for example. The verb "Damina" on the other hand is widely used in Classical Arabic in a variety of seemingly unrelated meanings.

Solidarity can be descriptive or normative. It is descriptive when talking about a kind of connection to other people, to describe and explain the normal order in a community, normative social interaction as opposed to chaos and conflict. Actions, motivations and attitudes can be described as more or less solidary. Solidarity is normative, as Rorty (1989) explains, when it covers all pro-social thought and action (we-thinking/us together). However, it should be separated from altruism and thou-centerism or religious charity. This sense requires a presumption of reciprocity and shared group membership. 


\section{Solidarity in Times of Crisis}

Habermas's main contribution to the debate is related to solidarity and globalization as he questions the concept's ability to overcome the national boundaries and develop an awareness of duty and cosmopolitan solidarity. In this respect, Habermas makes a distinction between civic and cosmopolitan solidarity. Civic solidarity refers to what unites members of a particular political group for example and it is what makes them defend the same political project. This type of solidarity has recently developed in western communities and thus joined and even triumphed over the more natural family and origin-based forms of solidarity. In this regard, civic solidarity has succeeded to become a more abstract idea binding people belonging to the same nation even if they are totally strangers to each other (Kobylinski, 2009, p. 144). In this regard, macro-level Cosmopolitan solidarity, on the other hand, is yet to be developed. Habermas maintains that this type of solidarity cannot be founded on a cosmopolitan identity or on some common idea of good but on a foundation of human rights vested in every individual (ibid. p. 144). One of the problems that can be raised in relation to the concept of cosmopolitan solidarity is that human rights themselves are a construct of western civilization.

i. In sociology and social psychology, solidarity has been conceived of either as a macrolevel phenomenon of group cohesion, integration or order or as a micro-level behavior, emotions solidarity is a reflection of the micro-level one as it translates the emotions and attitudes into tangible actions. The micro-level solidarity can be further clarified when looked at its distinctive features as made clear bellow.

\section{More on Solidarity: Distinctive Features and Situation Types}

For a better understanding of solidarity as a social action in this time of Covid 19 pandemic, it would be helpful to understand its distinctive features and the types of situations where solidarity is generally called for.

\section{Distinctive Features of Solidarity}

Social philosopher Larry May identifies five distinctive features of solidarity. These are given and exemplified bellow (Laitinen \& Bessi, 2014, p. 3):

a. Conscious identification with the group: the feeling of the individual that the group's well-being is part of its members' well-being is essential and constitutive to solidarity. Thus, the concept of solidarity is built on a sense of similarity and conformity. In other words, belonging to the same group makes the individuals feel alike and sharing the same interests. As in the commonly used expression: us Americans..., or us Moroccans.... 
b. Bonds of sentiment: feelings of compassion among the individuals based on the simple fact that they belong to the same group. Religious groups are a case in point. For example, Muslims manifest empathy for all other Muslims in distress.

c. Common interests in the group's well-being: this means that the group's welfare is put first before that of its individuals. This can be illustrated by the situation of Scandinavian communities where the taxes are very high but the people do not mind paying them since these taxes insure the whole group's comfort.

d. Shared values and beliefs such as common history, religion, and living in the same region: this seems to mean that solidarity always needs a justification. In other words; an answer for the question "why should I care?" is always required.

e. Readiness to show moral support: this feature of solidarity is most manifested when faced with adversity. That is to say, an individual is more likely to support those belonging to his own group against the others regardless of his own personal beliefs.

Equally important is the idea that solidarity by definition refers to practical disposition to action not mere passive feelings. Put simply, it is not enough to have or verbally express feelings of solidarity. It is important to translate those feelings into action. The following subsection clarifies the situation types in which solidarity can manifest.

\section{Situation Types of Solidarity}

According to Siegwart Lindenberg, solidarity manifests itself especially in five particular types of situations where there could be a temptation to act without solidarity. This means that in these situations the individual follows norms to take others into consideration in his or her actions, although pursuit for short-term pleasure or perhaps also personal long-term benefit would suggest acting differently in that particular situation. The five situation types are as follows:

a. Cooperation refers to situations where common good is produced. Both Ego and Alter belong to a group where common good is produced. Ego acts in a solidary manner if she participates in the production of common good even if it is arduous and even if there is an opportunity for free riding.

b. Fairness refers to situations of sharing. The Ego responsible for distributing burdens and benefits acts in accordance with solidarity if she strives to give everyone a fair amount of both benefits and burdens instead of attempting to maximize her own 


\section{Solidarity in Times of Crisis}

benefits and minimize her own burdens. What justice demands in detail is dependent on the accepted norms of the group.

c. Altruism refers to needs and helping situations. Ego acts in a solidary manner if she helps the Alter in distress. What is regarded as needs and what is considered the minimum amount of help needed for the behavior to be solidary, again depends on the shared interpretations within a group. These may differ in different groups.

d. Trustworthiness refers to situations of temptation where breaching implicit or explicit contracts would be tempting. Ego acts in a solidary manner if she avoids harming others even if it would mean increased costs for her.

e. Considerateness refers to situations where things go awry, and promises or contracts cannot be fulfilled. Here the Ego acts in a solidary manner if she apologizes, if possible, warns about this beforehand and strives to compensate for her breaches (Lindenberg, Fetchenhauer, Flache \& Bruunk (2006, 9) in Laitinen \& Bessi, 2014, p. 5).

As it turns out then, the distinctive features of solidarity show that a number of shared values, interests or background is always needed for people to act in a solidary manner while the situation types of solidarity shed some light on the ways different individuals can adopt to show their solidarity. The following section discusses in more detail the foundations of this shared culture that may induce individuals to solidary actions or otherwise anti-solidary ones.

\section{Solidarity and Social Groups: Community, Society, and the World}

It is difficult to talk about solidarity outside a certain community in the sense that solidarity is in essence closely connected to communality. Additionally, it is in small communities that solidarity's characteristics may materialize most clearly for the simple reason that the members of such communities share, among other things, common history, common language, feeling of cohesion, willingness to help each other, common beliefs, and systems of values and norms. Therefore, it seems that the core feature of solidarity is inclusion and exclusion: not everyone is a member. This attitude promotes and in part specifically creates feelings of cohesion and density of a group. Respectively, outsiders may have their own communities. Any agent may have some responsibilities towards anyone, but typically shares their life more intensively with the particular members of one's own group. In contrast, it seems that the most solid communities are the ones which emphasize their difference to other communities. Such communities include fanatical religious groups and political groups. This aspect of solidarity makes the analysis of the concept trickier. In other words, what can be the very foundation of 
solidarity i.e., the common history, religion, language, etc. is also what sets people apart and provokes them to act in an anti-solidary manner towards outsiders to their social group.

In entire societies, solidarity manifests itself in different ways, depending on the perspective and discipline. In a sense, it is the social glue, or the cement of the society. This refers to the types of social bonds that cannot be traced back to coercive power or self-interest. Crucially, societal solidarity raises the essential question of the way various goods are distributed in the society in the first place. In this discourse, the most central topics are income distribution, social services, and taxation: for example, in the Nordic welfare states, the high level of taxation and social services is justified through solidarity. So instead of basing the distribution of societal revenue on voluntary charity, the right of each individual to basic income and acceptable living conditions has been institutionalized (Laitinen \& Bessi, 2014, p. 9).

At the level of the entire humanity, it is not impossible that the whole world might one day form one comprehensive global state or society where national solidarity would cover all individuals, but it is not clear whether humanity at its current size could be a "concrete society" in the proper meaning of the term. Also, is it possible at all to consider all humanity and political solidarity? Can the entire humankind bond into one political movement to confront say climate change, genocides, or pandemics? Ecological issues, for instance, have garnered support from an ever-growing mass of individuals around the globe. Yet, the ecological movement still has its opponents and people who treat the issue with indifference. This, however, does not as such diminish its global nature any more than the existence of crime in a society diminishes the "societal" nature of the laws or solidarity of that society (Laitinen, \& Bessi, 2014, p. 11).

Furthermore, the moral perspective of altruism or equal respect is essential at the level of human solidarity. The altruistic perspective is a feeling of connection to other people; a feeling that the helper often finds difficult to articulate. Instead of dividing people into us and them, altruists perceive all individuals as members of the general humankind. When investigated, many individuals who have committed an altruistic deed that has been considered heroic have simply stated: "It was the only thing I could have done. They are people, just like me" (ibid. p.11). This example clearly illustrates the concept of humanitarian solidarity or cosmopolitan solidarity in Habermas's terminology. This form of solidarity can be seen as one variety of solidarity: humanitarian solidarity which is based on the notion of unity of all humanity.

\section{Discussion}

Covid 19 pandemic has indeed caused a universal complex crisis at so many levels. A crisis is by definition often linked to the concept of psychological stress and used to suggest a 


\section{Solidarity in Times of Crisis}

frightening or fraught experience. It is the situation of a "complex system" when the system functions poorly or doesn't function at all: the system being anything from a small family to an entire country's economy and perhaps to the whole world safety as in the crisis caused by Covid 19 pandemic. Additionally, a crisis is usually unexpected. In other words, if people and nations can have the luxury to be prepared to face a crisis, they'd better avoid it in the first place.

Times of crisis constantly call for solidarity, both at the level of individuals and nations. However, the aforementioned characteristics of the concept all stress a kind of internalized sense of uniformity and similarity on which solidary behavior is always built, never diversity. In fact, it is much easier to express one's solidarity towards others who belong to the same group, be it ethnic, religious, political or even fanatical. With larger groups, showing solidarity becomes much more difficult as it becomes harder to find shared cultural features among culturally distant communities. Particularly, in this time of Corona outbreak, what would be people's shared objectives and shared interests?

In the Moroccan context, it would seem that solidarity has been crucial in partly surmounting the crisis as the King Muhammad 6 has initiated a case for Corona crisis by which a significant amount of money was raised through donations from companies and individuals then distributed to the people who were most affected by the crisis during the three months of the quarantine. The amount of 15.26 billion dirhams was devoted to TaDaamun "solidarity" operation for the benefit of the poor in the form of supporting donations varying between $800 \mathrm{dhs}$ and $1200 \mathrm{dhs}$ according to the family size. Another 6.1 billion went to people who had lost their jobs because of the pandemic (The Project of the Law of Finance, 2021, p. 11). Additionally, baskets of necessary household supplies were distributed both by the government and associations. Moreover, the national law of finance outlined for the year 2021 is marked by positing a solidary contribution on both salaries and companies starting from $1.5 \%$ (Aljarida Rrasmia, 2021, n 65.20). All these and other efforts, however, remained insufficient especially because poverty is more of a structural problem with deep roots pertaining to the country's policy regarding the distribution of income. Additionally, the reason why managing the Corona case was not given to the Ministry of Solidarity, Social Development, Equity and Family remains obscure. More solidarity programs are definitely needed in particular with the economic crisis getting more critical with time.

Even in countries in which solidarity is more institutionalized, Covid 19 pandemic revealed deep deficiencies in the systems. Even if solidarity is formally one of six principles of the 
charter of fundamental rights of the European Union, this didn't seem to help with all the predicaments the pandemic caused in Italy and Spain for example. The European union turned out not so united after all, and the countries not belonging to the European union were showing more solidarity; cases in point: Turkey and China, themselves suffering from the pandemic all the same no matter what their actual motivations are.

Another important dimension necessarily implied by the concept of solidarity is a sense of action. Feelings and ideas can also be solidary but they don't really count unless they are translated or reflected by actions. In fact, solidarity in general brings about a good feeling about oneself, but in times of severe social or global crises, it can be a life-threatening act, the more solidary you act, the more unsafe you feel. In this respect, only the altruistic perspective of solidarity is feasible. In other words, solidarity at the level of the whole humanity requires a sense of sacrifice at the expense of one's own personal benefits.

Some legitimate questions are imposed at this point: How can sympathy be created between groups in times of danger? And how can society be bound as one when everyone fears for his own life? Reality shows that such attitudes are nearly rare as has been noticed in the ongoing crisis. Scenes of people rushing to buy huge quantities of food, toilet paper and gas around the globe are all over the news while social networks abound with pictures, videos and campaigns of people distributing food to the needy. Does this mean that people act in two contradictory ways at the same time? Is there a sense of hypocrisy in the way solidarity is manifested in social networks?

To put it bluntly, it seems that survival instincts are activated at once in times of crisis: perhaps not at the same pace among individuals and nations but they do eventually. That is, a person's life becomes more invaluable than any other's in his opinion. Having enough food, medication, and isolation from the source of trouble all become vital. The general attitude becomes, "l'autre c'est l'enfer". Even if some people lose their lives due to the pandemic, no time is devoted to mourning. The dead person is just a number and there is definitely no time to celebrate his achievements in a proper funeral.

Panic buying of certain basic goods despite the fact that there was no indication of shortage reveals individuals' anxiety. The person who would go and buy tons of food and supplies is somehow thinking with his survival instinct (in an animal-like fashion) and forgets all about what makes him human in the first place, i.e., a social being should normally think of others before he acts. In this regard, the only situation type that is possibly helpful is that of altruism, i.e., when solidarity is no need of justification as explained above. Solidarity is really needed 


\section{Solidarity in Times of Crisis}

in times of war, not times of peace, times of sickness, not times of health, times dearth, not times of wealth. Indeed, there seems to be a pressing need both at the macro and micro levels to redefine solidarity on more practical grounds.

At a macro level, it is not social cohesion only that should be sought, it is human cohesion. Social cohesion is conditioned by many shared factors that are the foundations of social solidarity. Human cohesion, as a basis for human solidarity is more effective. It is unconditioned by shared objectives or any cultural components. Tomasini (2021) goes farther as highlighting another level of solidarity, biocentric solidarity which takes into consideration all forms of life in the sense of Fritz Jahr concept of bioethics. In this sense, solidarity would take into account all species going thus beyond all the levels discussed above.

\section{Conclusion}

To conclude, in this paper we have tried to understand the action of solidarity as it is manifested in the time of Corona virus outbreak. It has been shown that the very confusion people seem to go through between being solidary or not finds its origins in the development of the concept itself. The most common type of solidarity comes naturally in smaller groups where so much is shared. As the group gets larger, solidarity becomes difficult and in need of more work and improvement. Global crises in particular really put all the human culture at stake. If individuals and nations keep performing in the way they have in Covid 19 pandemic, solidarity will not find its place amongst them. In contrast, if they come to lend a hand to each other whenever needed for the simple reason that a crisis in one nation would surely affect all the others one way or another, then human solidarity or Habermas's cosmopolitan solidarity will finally come to reality. Indeed, it is the role of education to build this more solid human sense of solidarity among people based on more established universal norms going beyond immediate pragmatic ends.

\section{References}

Alfiras, M., Bojiah, J., \& Yassin, A. A. (2020). COVID-19 pandemic and the changing paradigms of higher education: A Gulf university perspective. Asian EFL Journal, 27(5), $1-9$.

Alhambra, C. N. \& Navarro, E. (2021). Creating Covid-19 Health Protocol Communication material in Filipino: A translation study. International Journal of Language and Literary Studies, 3(1), 240-261. 
Al-Mandhari, A. Kodama, C. Abubakar, A. \& Brennan, R. (2020). Solidarity in response to Covid-19 outbreak in the Eastern Mediterranean Region. Eastern Mediterranean Health Journal 26(5), 492-494.

Habermas, J. (2013). Democracy, Solidarity and the European Crisis. In: A Roadmap to a Social Europe. Edited by Anne-Marie Grozelier, Björn Hacker, Wolfgang Kowalsky, Jan Machnig, Henning Meyer and Brigitte Unger

Kobylinski, A. (2009). The Role of Solidarity in an Open Society. In: Europske kontexty Interkulturnej Komunikacie [European Context of Intercultural Communication], edited by Peter Ivanic, Martin Hetenyi and Zvonko Taneski, 139-148.

Laitinen, A. \& Bessi, A. B. (2014). Solidarity: Theory and Practice. Lexington Books.

O’Connell, M. de Paula, A. \& Smith, K. (2021). Preparing for a pandemic: Spending dynamics and panic buying during the Covid-19 first wave. Fiscal Studies, 42(2).

Pensky, M. (2000). Cosmopolitanism and the Solidarity Problem: Habermas on National and Cultural Identities. Constellation. Vol 7, N. 1

Rorty, R. (1989). Contingency, Irony, and Solidarity. Cambridge University Press.

The Government of Economy, Finance, and Administration Reforming. (2021). The Citizen's Budget: The Project of the Law of Finance. The Citizen's Guide to Learn about the Law of Finance.

Tomasini, F. (2021). Solidarity in the time of Covid-19? Cambridge Quarterly of Health Care Ethics, 30, 234-247.

\section{$\underline{\text { AUTHOR'S BIO }}$}

Boutabia Amina is a doctorate candidate at the University of Chouaib Doukkali, ElJadida, Morocco. The doctoral project she is working on is entitled "The Construct State in Moroccan Amazigh". She is interested in theoretical linguistics namely syntax and morphology. She is also interested in other fields of research such as translation, and sociology. 